\title{
FENOMENOLOGI PEMAHAMAN DAN MAKNA KIP OLEH PPID DINAS PARIWISATA PROVINSI SUMATERA BARAT
}

\author{
Rahmadhona Fitri Hemi \\ Jurusan Ilmu Administrasi Negara, FIS, Universitas Negeri Padang \\ rahmadhonafh@fis.unp.ac.id \\ Karjuni Dt Maani \\ Jurusan Ilmu Administrasi Negara, FIS, Universitas Negeri Padang \\ karjuni.dtmaani@fis.unp.ac.id

\begin{abstract}
Aldri Frinaldi
Jurusan Ilmu Administrasi Negara, FIS, Universitas Negeri Padang aldri@fis.unp.ac.id
\end{abstract}

\begin{abstract}
The ability of the government to provide the availability of information with a variety of infrastructure and adequate content, accompanied by an attitude of openness and adequate mechanisms and procedures will facilitate the public to contribute or participate positively. The provision of information in the government is carried out by Public Information Management Officers (PPID) in each Public Agency. This research was conducted to find out how the understanding of PPID in the West Sumatra Province Tourism Office towards public information disclosure, knowing the meaning of information applicants and knowing the meaning of public information openness by the PPID in the West Sumatra Province Tourism Office. The method used in this study is a qualitative method with a phenomenological approach. The results showed that the understanding of PPID in the West Sumatra Province Tourism Office towards public information disclosure is quite good. The PPID is able to take responsibility for the mandate of Law Number 14 Year 2008 on Public Disclosure of information, which is responsible for storing, documenting and providing public information by supplying public information data available at the West Sumatra Province Tourism Office to the PPID in West Sumatra Province Government. The meaning of information applicants for PPID in the Tourism Office of West Sumatra Province is as a party that must be served and has the right to obtain public information because they are guaranteed by the Public Disclosure of information Law. While the meaning of public information disclosure for PPID in the West Sumatra Province Tourism Office is the guarantee for the public to get information from public agencies.
\end{abstract}


Keywords: Public Information Disclosure Act, Information Public, Officials Manager of Information and Documentation

How to Cite: Rahmadhona Fitri Helmi, dkk. 2020. Fenomenologi Pemahaman dan Makna KIP oleh PPID Dinas Pariwisata Provinsi Sumatera Barat. Vol 4 (1): pp. 112-124. DOI: https://doi.org/10.24036/jess/vol4-iss1

\section{Pendahuluan}

Tingkat kebutuhan akan informasi meningkat apabila informasi tersebut memberikan sesuatu yang bermanfaat kepada sipencarinya, seperti menyelesaikan masalah atau memecahkan persoalan, memberikan ide-ide baru untuk sebuah program baru, kebutuhan pada pengetahuan, atau melakukan pengawasan pada sesuatu yang sedang berjalan. Kemampuan penyelenggara pemerintahan menyiapkan sediaan informasi dengan berbagai infrastruktur dan konten yang memadai, disertai dengan sikap keterbukaan dan mekanisme serta prosedur yang memadai, akan memudahkan masyarakat untuk berkonstribusi atau berpartisipasi secara positif. Masyarakat tidak akan mudah terpancing isu atau informasi yang simpang siur seandainya mereka dapat dengan mudah memperoleh informasi yang memadai (Setiaman, Sugiana, Narotama M, 2013:196).

Kebebasan memperoleh informasi merupakan salah satu hak asasi yang dimiliki individu dimana pun mereka berada. Bahkan ciri dari Negara yang menganut prinsip-prinsip demokrasi adalah: a) menjamin hak publik untuk memantau dan mengamati perilaku pejabat publik dalam menjalankan fungsi publiknya; b) menjamin publik untuk mendapatkan informasi; c) menjamin hak publik untuk berpartisipasi dalam pembentukan kebijakan publik; d) menjamin publik untuk dilindungi dalam mengungkapkan fakta dan kebenaran; e) menjamin hak/ kebebasan berekspresi yang diwujudkan melalui kebebasan pers yang berkualitas; dan f) menjamin publik untuk mengajukan keberatan (Jebarus, 2014:184). Sejalan dengan itu, Amandemen UUD 1945, ayat 28F menyatakan bahwa "Setiap orang berhak untuk berkomunikasi dan memperoleh informasi untuk tujuan pengembangan dirinya dan lingkungan sosial, dan berhak untuk mencari, memperoleh, memiliki, menyimpan, memproses dan menyampaikan informasi dengan menggunakan semua jenis saluran yang tersedia" (Lubis, 2018:95).

Adanya Undang-undang Nomor 14 Tahun 2008 tentang Keterbukaan Informasi Publik (KIP), masyarakat dijamin haknya untuk memperoleh informasi dari lembaga pemerintah, Undang-Undang ini juga menuntut setiap lembaga yang termasuk dalam kategori Badan Publik untuk dapat menyediakan dan menyebarluaskan informasi publik secara transparan kepada masyarakat. Informasi publik adalah hak dasar yang harus dipenuhi oleh Badan Publik untuk disebarluaskan kepada publik. Undang-Undang KIP menyatakan bahwa setiap orang dapat memperoleh informasi publik berdasarkan ketentuan hukum. Keterbukaan informasi publik adalah cara untuk mengoptimalkan pengawasan publik terhadap negara dan badan publik. Ketika informasi disajikan dengan kemasan yang baik, maka itu akan dapat 
meningkatkan partisipasi publik dan memperkuat hubungan antara masyarakat dan badan publik (Helmi, 2017:158).

Terdapat empat jenis informasi publik dalam Undang-Undang KIP: 1) Informasi yang wajib disediakan dan diumumkan secara berkala, informasi ini disediakan secara rutin, teratur, dan dalam jangka waktu tertentu setidaknya setiap 6 bulan sekali. Informasi ini mencakup: a) informasi berkaitan dengan Badan Publik (profil, kedudukan, kepengurusan, maksud, dan tujuan didirikannya badan publik), b) informasi kegiatan dan kinerja Badan Publik, informasi tentang laporan keuangan, dan c) informasi lain yang diatur dalam peraturan perundang-undangan; 2) Informasi serta merta, yakni informasi yang wajib diumumkan tanpa penundaan menyangkut ancaman terhadap hajat hidup orang banyak dan ketertiban umum. Informasi ini terkait dalam bidang riset, teknologi, dan pendidikan tinggi yang dapat mengancam hajat hidup orang banyak dan ketertiban umum. 3) Informasi setiap saat, informasi ini merupakan informasi tentang peraturan, keputusan dan kebijakan badan publik, 4) Informasi yang dikecualikan, sifatnya rahasia dan tidak dapat diakses oleh publik sesuai dengan kriteria yang diatur dalam Pasal 17 Undang-Undang KIP.

Hasil monitoring dan evaluasi terhadap 460 Badan Publik di seluruh Indonesia yang dilakukan oleh Komisi Informasi Pusat Republik Indonesia, hanya sebanyak 289 atau sekitar $62,83 \%$ Badan Publik yang berhasil mengembalikan kuesioner penilaian. Melihat dari prosentase tersebut, secara garis besar, harus digarisbawahi bahwa Keterbukaan Informasi Publik di Indonesia masih jauh dari tujuan yang diamanatkan Undang-Undang KIP, karena masih banyaknya Badan Publik yang belum melaksanakan Undang-Undang KIP. Hal ini menjadi pekerjaan bersama dengan menekankan pada masih diperlukannya dorongan yang lebih besar untuk menjadikan keterbukaan informasi sebagai budaya untuk mewujudkan tata kelola pemerintahan baik dan bersih (KI Pusat Republik Indonesia, 2018).

Sejalan dengan itu, Kepala Bidang Pengelolaan Informasi dan Komunikasi Publik, Dinas Kominfo Sumbar pada kegiatan Focus Group Discussion (FGD), mengatakan bahwa pada tahun 2018 terdapat 2.000 lebih Daftar Infomasi Publik (DIP) di Provinsi Sumatera Barat. Namun demikian, masih terdapat perbedaan pandangan dalam memberikan informasi yang semestinya dibuka kepada masyarakat umum. Sering terjadi miss communication pemahaman antara pimpinan dan bawahan, karena tidak adanya pemahaman terkait informasi publik tersebut, mana yang harus dibuka dan mana yang tidak.

Keterbukaan informasi publik tidak terlepas dari pemahaman dan pemaknaan dari Undang-Undang KIP no.14 tahun 2008 oleh PPID Pembantu Dinas Pariwisata Provinsi Sumatera Barat sebagai aktor pelaksana dari Undang-Undang tersebut. Penelitian ini dimaksudkan untuk mengetahui bagaimana pemahaman PPID di Dinas Pariwisata Provinsi Sumatera Barat terhadap keterbukaan informasi publik, mengetahui makna pemohon informasi dan mengetahui makna keterbukaan informasi publik oleh PPID Pembantu di Dinas Priwisata Provinsi Sumatera Barat. 


\section{Tinjauan Kepustakaan}

\section{Pemahaman Informasi Publik}

Informasi menjadi salah satu kebutuhan dasar yang dibutuhkan sebagai pribadi, sebagai anggota masyarakat, dan sebagai warga negara. Konsep negara demokrasi memandang bahwa penyelenggaraan pemerintahan merupakan amanat rakyat. Oleh karena itu, segala informasi yang dihasilkan dan mengenai penyelenggaraan pemerintah tersebut, merupakan milik rakyat sebagai pemberi mandat. Dengan demikian, sudah selayaknya jika informasi menjadi milik publik. Inilah yang menjadi dasar bahwa informasi publik bersifat terbuka dan dapat diakses (Subagyo dalam Lareta, 2014: 21). Informasi publik menurut Undang-Undang KIP adalah keterangan, pernyataan, gagasan, dan tanda-tanda yang mengandung nilai, makna, dan pesan, baik data, fakta maupun penjelasannya yang dapat dilihat, didengar dan dibaca yang disajikan, dalam berbagai kemasan dan format sesuai dengan perkembangan teknologi informasi dan komunikasi, secara elektronik ataupun nonelektronik (Pasal 1 ayat 1 UU KIP).

Undang-Undang KIP juga mengatur kategori-kategori informasi yang disediakan bagi sebuah badan publik. Pengkategorisasian jenis informasi membantu sebuah badan publik untuk lebih mudah memilah-milah mana informasi yang wajib disediakan secara berkala, mana informasi yang disediakan serta merta, mana informasi yang harus ada setiap saat, dan mana pula informasi yang sifatnya dikecualikan. Kriteria tersebut dapat dilihat pada gambar 1. di bawah ini.

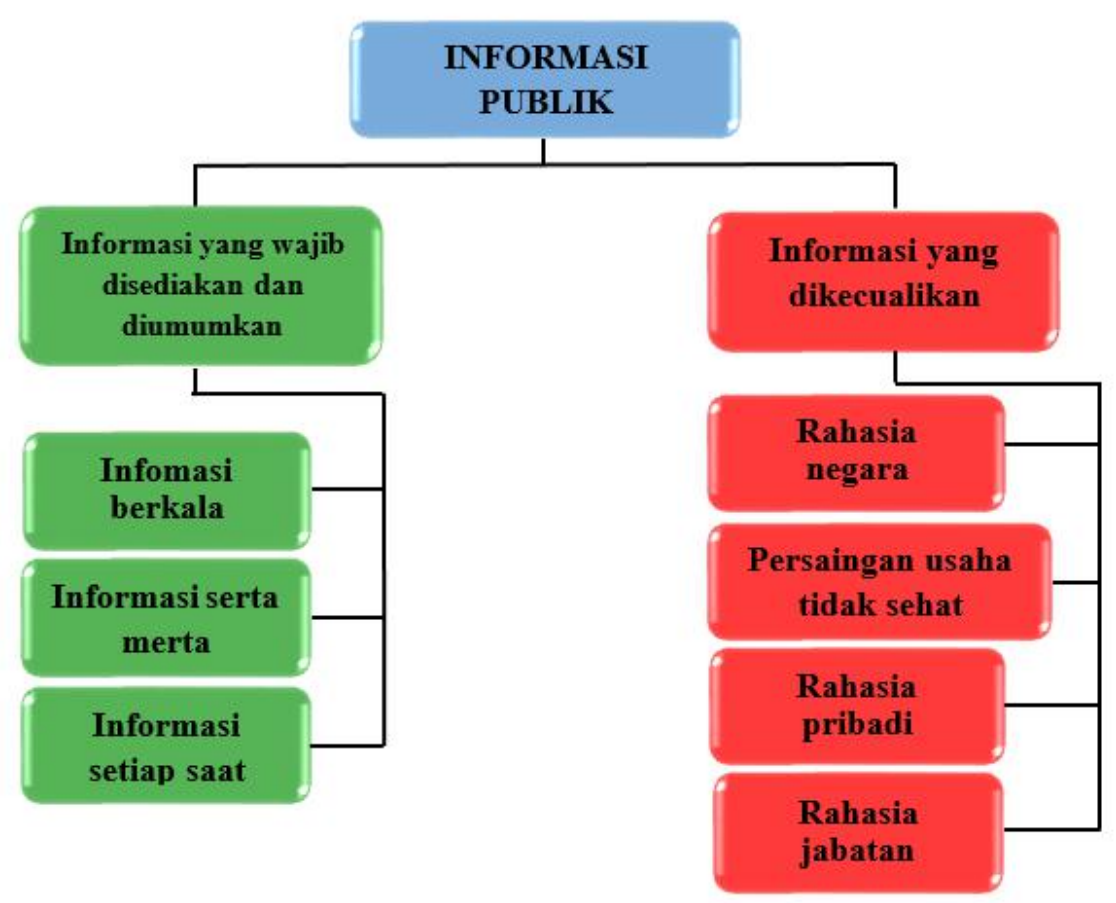

Gambar. 1 Kategori Informasi Publik berdasarkan Undang-Undang KIP 
Adanya kategorisasi jenis informasi ini akan dapat memudahkan masyarakat untuk mengetahui apa-apa saja informasi yang berhak mereka minta ataupun mereka akses. Dengan demikian, masyarakat diharapkan dapat memperoleh akses informasi secara cepat, mudah, dan murah. Sehingga tercipta keterbukaan antara pemerintah dengan masyarakat. Kebebasan memperoleh informasi merupakan salah satu prasyarat untuk menciptakan pemerintahan terbuka (open government). Pemerintahan terbuka adalah penyelenggaraan pemerintahan yang bersedia untuk diawasi publik. Maka penyelenggaraan negara semakin dapat dipertanggungjawabkan, yaitu terciptanya tata kelola yang baik dengan penerapan beberapa indikator antara lain; keterbukaan, partisipasi, akuntabilitas, efektivitas dan koherensi (Subagyo dalam Lareta, 2014:22-23).

\section{Makna Keterbukaan Informasi Publik}

Untuk mewujudkan tujuan negara, maka pemerintah mempunyai tanggungjawab menciptakan tata kelola pemerintahan yang baik (good governance). Salah satu indikator terciptanya penyelenggaraan pemerintahan yang baik adalah terpenuhinya syarat transparansi informasi. Transparansi dalam Undang-Undang KIP, dimaknai dengan keterbukaan dalam melaksanakan proses pengambilan keputusan, dan keterbukaan dalam mengemukakan informasi materil dan relevan mengenai badan publik. Transpararansi juga dipahami sebagai keterbukaan pemerintah, dalam memberikan informasi terkait aktivitas pengelolaan sumber daya publik, kepada pihak-pihak yang membutuhkan informasi. Transparansi adalah berbagi informasi secara terbuka tentang organisasi baik positif atau negatif. Sehingga mampu meningkatkan akuntabilitas organisasi di mata masyarakat (Lareta, 2014:20).

Transparansi pada konteks penyelenggaraan pemerintah daerah, tidak jauh berbeda dengan pemerintah pusat. Sebagaimana diketahui, pemerintah daerah diberi wewenang untuk mengatur, dan mengurus sendiri urusan pemerintahan, dan kepentingan masyarakat setempat sesuai dengan peraturan perundang-undangan. Format dan konsep transparansi yang diimplementasikan dalam penyelenggaraan pemerintahan daerah, merupakan penjabaran lebih lanjut dari satu asas-asas umum. Sebagaimana diatur dalam UU No. 28 Tahun 1999 tentang Penyelenggaraan Negara yang Bersih dan Bebas KKN. Hal ini selaras dengan apa yang diamanatkan dalam Undang-Undang KIP (Lareta, 2014:23).

Asas keterbukaan dalam penyelenggaraan pemerintah daerah menurut Tahir adalah asas yang membuka diri terhadap hak masyarakat dalam memperoleh informasi yang benar, jujur dan tidak diskriminatif, tetap mempertimbangkan hak asasi pribadi, golongan maupun rahasia negara. Penerapan transparansi memberikan peluang kepada masyarakat untuk mengetahui berbagai informasi terkait penyelenggaraan pemerintahan. Sehingga dengan adanya keterbukaan akan meningkatkan akuntabilitas pemerintah di mata masyarakat

Sedangkan menurut pendapat Dwiyanto, keterbukaan memberikan kesempatan kepada masyarakat luas untuk mengetahui berbagai macam informasi mengenai penyelenggaraan pemerintah, hal ini akan mempermudahkan upaya masyarakat dalam menilai keberpihakkan pemerintah terhadap publik. Masyarakat dapat secara mudah menentukan apakah akan memberikan dukungan kepada pemerintah atau malah sebaliknya (Lareta, 2014:23-24). 


\section{Teori Interaksi Simbolik (Symbolic Interactionism)}

Teori Interaksionisme Simbolik (symbolic Interactionism) tidak bisa dilepaskan dari pemikiran George Harbert Mead (1863- 1931). Mead adalah seseorang yang memiliki pemikiran yang original dan membuat catatan kontribusi kepada ilmu sosial dengan meluncurkan "the theoretical perspective" yang pada perkembangannya menjadi cikal bakal Teori Interaksi Simbolik (Siregar, 2011:100). Menurut Mead, makna muncul sebagai hasil interaksi di antara manusia, baik secara verbal maupun nonverbal. Melalui aksi dan respons yang terjadi, kita memberikan makna kedalam kata-kata atau tindakan, dan karenanya kita dapat memahami suatu peristiwa dengan cara-cara tertentu. Menurut paham ini masyarakat muncul dari percakapan yang saling berkaitan di antara individu (Morissan, 2013:126).

Teori ini memfokuskan perhatiannya pada cara-cara yang digunakan manusia untuk membentuk makna dan struktur masyarakat melalui percakapan. Dalam deskripsi Mead, proses "pengambilan peran" menduduki tempat penting. Karena interaksi berarti bahwa para peserta masing-masing memindahkan diri mereka secara mental ke dalam posisi orang lain. Dengan berbuat demikian mereka mencoba mencari arti maksud yang oleh pihak lain diberikan kepada aksinya, sehingga komunikasi dan interaksi dimungkinkan. Jadi, interaksi tidak hanya berlangsung melalui gerak-gerik saja, melainkan melalui simbol-simbol yang perlu dipahami dan dimengerti maknanya. Artinya, gerak yang menentukan. Dalam interaksi simbolik orang mengartikan dan menafsirkan gerak-gerik orang lain yang bertindak sesuai dengan arti itu (Sobur, 2017: 195).

Terdapat tiga konsep penting dalam teori yang dikemukakan Mead dalam (Morissan, 2013: 127-132), yaitu: pertama, Masyarakat; masyarakat terdiri atas perilaku yang saling bekerja sama di antara para anggotanya. Syarat untuk dapat terjadinya kerja sama adalah adanya pengertian terhadap keinginan atau maksud orang lain, tidak saja pada saat ini tetapi juga pada masa yang akan datang. Dengan demikian, kerja sama terdiri atas kegiatan untuk membaca maksud dan tindakan orang lain dan memberikan tanggapan terhadap tindakan itu dengan cara yang pantas. Makna adalah hasil komunikasi yang penting. Makna yang kita miliki adalah hasil interaksi kita dengan orang lain. Dengan demikian, jelaslah kita tidak dapat berkomunikasi dengan orang lain tanpa memiliki makna bersama terhadap simbol yang kita gunakan. Konsep kedua adalah konsep Diri, yaitu; manusia sangat diperngaruhi oleh orang-orang yang berada dalam lingkungan terdekatnya. Orang-orang terdekat adalah mereka yang memiliki hubungan dan ikatan emosional seperti orang tua dan saudara. Mereka memperkenalkan kata-kata baru, konsep-konsep tertentu atau kategori-kategori tertentu yang memberikan pengaruh kepada seseorang dalam melihat realitas. Orang terdekat membantu seseorang belajar membedakan antara dirinya dengan orang lain sehingga memiliki "rasa diri" (sense of self). Dapat diartikan bahwa konsep diri adalah keseluruhan persepsi seseorang mengenai cara orang lain melihat dirinya.

Konsep Mead yang Ketiga adalah pikiran, kemampuan menggunakan simbol-simbol signifikan untuk menanggapi diri memungkinkan anda berpikir, ini merupakan konsep Mead yang dinamakan pikiran (mind). Pikiran bukanlah suatu benda, tetapi suatu proses yang tidak lebih dari kegiatan interaksi dengan diri sendiri. Kemampuan berinteraksi yang berkembang 
bersama-sama dengan diri sendiri sangat penting bagi kehidupan manusia karena menjadi bagian dari setiap tindakan. Berpikir melibatkan keraguan (menunda tindakan terbuka) ketika menginterpretasikan situasi. Berpikir sepanjang situasi dan merencanakan tindakan ke depan, membayangkan berbagai hasil, memilih alternatif dan menguji berbagai alternatif yang mungkin terjadi.

\section{Teori Interaksi Simbolik (Symbolic Interactionism) George Herbert Mead dalam Pemahaman dan Makna Keterbukaan Informasi Publik}

Melalui tiga konsep dalam teori interaksionisme simbolik milik George Herbert Mead, peneliti bermaksud untuk menjelaskan pemahaman dan makna keterbukaan informasi publik oleh PPID Pembantu di Dinas Pariwisata Provinsi Sumatera Barat. Diantaranya, pemahaman PPID Pembantu tentang informasi publik yang diamanatkan Undang-Undang KIP nomor 14 tahun 2008, mengetahui makna pemohon informasi publik, dan mengetahui makna keterbukaan informasi publik. Adapun tiga konsep Mead tersebut diantaranya: 1) masyarakat; 2) diri; dan 3) pikiran, maka penelitian ini berusaha menjelaskan perspektif didalam individu, yaitu PPID Pembantu di Dinas Pariwisata Provinsi Sumatera Barat.

\section{Metode Penelitian}

Penelitian ini menggunakan metode kualitatif dengan pendekatan fenomenologi. Metode kualitatif yaitu penelitian yang bermaksud untuk memahami fenomena tentang apa yang dialami oleh subjek penelitian misalnya perilaku, persepsi, motivasi, tindakan dan lain-lain, secara holistik dan dengan cara deskripsi dalam bentuk kata-kata dan bahasa, pada suatu konteks khusus yang alamiah dan dengan memanfaatkan berbagai metode ilmiah (Moleong, 2017:6). Sedangkan, pendekatan fenomenologi, yaitu suatu pendekatan yang mencoba mencari pemahaman bagaimana manusia mengkontruksi makna dan konsep-konsep penting dalam kerangka intersubjektif karena pemahaman seseorang mengenai dunia dibentuk oleh hubungan kita dengan orang lain. Secara harfiah, fenomenologi adalah studi yang mempelajari fenomena, seperti penampakan, segala yang muncul dalam pengalaman seseorang, cara seseorang mengalami sesuatu, dan makna yang dimiliki seseorang dalam pengalamannya. Namun dalam hal ini fenomenologi lebih luas dari sekedar fenomena, yakni pengalaman sadar dari sudut pandang orang pertama (yang mengalami secara langsung) (Supriatna, 2016:32).

Metode kualitatif dengan pendekatan fenomelogi ini sangat sesuai dengan orientasi teori interaksionisme simbolik, yaitu interaksi manusia yang saling menginterpretasikan tindakan masing-masing melalui penggunaan simbol-simbol untuk memperoleh pemahaman makna (Laksmi, 2017:126). Selanjutnya penelitian mencari kerangka teori, kemudian membentuk kategori dalam metode, operasionalisasi konsep, mengajukan pertanyaan dalam wawancara dan mengumpulkan data dan informasi berhubungan dengan teori-teori tersebut. Termasuk didalamnya peristiwa, peran, interaksi dan kelompok. Metode kualitatif merupakan sebuah proses investigasi (Supriatna, 2016:32).

Informan pada penelitian ini dipilih dengan menggunakan teknik purposive sampling, menurut Sugiyono, (2015:218) purposive sampling adalah teknik pengambilan sampel 
sumber data dengan pertimbangan tertentu, yakni sumber data dianggap paling tahu tentang apa yang diharapkan, sehingga mempermudah peneliti menjelajahi situasi sosial yang diteliti. Adapun yang menjadi informan penelitian ini adalah PPID Pembantu (Taufik Ramadhan, MM) di Dinas Pariwisata Provinsi Sumatera Barat. Pengumpulan data penelitian dilakukan dengan 3 cara, yaitu observasi, wawancara mendalam dan dokumentasi. Analisis data dilakukan pada saat pengumpulan data berlangsung dan setelah selesai pengumpulan data dalam periode tertentu. Pada saat wawancara, peneliti sudah melakukan analisis terhadap jawaban yang diwawancarai. Apabila jawaban yang diwawancarai setelah dianalisis dirasa belum menjawab pertanyaan dan memuaskan, maka peneliti akan melanjutkan pertanyaan kembali, sampai tahap tertentu diperolehnya data yang dianggap kredibel (Sugiyono, 2015:246 ). Aktivitas dalam analisis data, yaitu data reduction, data display, dan conclusion drawing/ verification.

\section{Hasil Penelitian dan Pembahasan}

\section{Pemahaman PPID Pembantu terhadap Undang-Undang KIP No. 14/2008}

Berikut ini adalah wawancara dengan Bapak Taufik Ramadhan, MM mengenai pemahamannya mengenai Undang-Undang Keterbukaan Informasi Publik no. 14 Tahun 2008 adalah sebagai berikut:

"Menurut saya, Undang-Undang Keterbukaan Informasi Publik no. 14 Tahun 2008 menyimpan amanah agar setiap Badan Publik mengelola seluruh informasi yang ada di dalam instansi/ organisasi mereka secara rapi dan menyebarluaskannya kepada masyarakat tanpa harus mempersulit masyarakat itu sendiri. Jika Undang-Undang Keterbukaan Informasi Publik no. 14 Tahun 2008 mampu diimplementasikan dengan baik, ini akan menjadi modal berharga bagi kemajuan pengelolaan pemerintahan di Indonesia karena aturan ini menyimpan misi untuk membentuk pemerintahan yang transparan dan akuntabel, sehingga berbagai kekeliruan dalam penyelenggaraan pemerintahan dapat diminimalisir melalui penegakan aturan ini. Bagi kami pemahaman Undang-Undang Keterbukaan Informasi Publik no. 14 Tahun 2008 yang dibentuk melalui Undang-Undang ini di setiap badan publik. PPID adalah pejabat yang bertanggung jawab di bidang penyimpanan, pendokumentasian, penyediaan, dan/atau pelayanan informasi di badan publik. PPID bertanggungjawab ke atasan di masing-masing badan publik. Setiap badan publik harus menunjuk PPID masing-masing dan mengembangkan sistem layanan informasi yang cepat, mudah dan wajar. PPID harus membuat uji konsekuensi dengan saksama dan penuh ketelitian sebelum menyatakan sebuah informasi yang dikecualikan dapat diakses atau tidak. Tanggungjawab dan wewenang PPID lebih lengkapnya diatur melalui Peraturan Pemerintah no. 61 tahun 2010

Berdasarkan penjelasan diatas, memperlihatkan PPID Pembantu Dinas Pariwisata Provinsi memahami Undang-Undang Keterbukaan Informasi Publik No. 14 Tahun 2008. Beliau memaparkan bahwa Undang-Undang KIP mengamanatkan kepada semua Badan 
Publik untuk mampu mengelola seluruh informasi di instansi masing-masing, yang nantinya informasi tersebut dapat disebarluaskan kepada masyarakat tanpa mempersulit akses.

Menurut Suryabrata (1991:298) dalam Supriatna (2016:43), Pemahaman dapat diartikan menguasai sesuatu dengan pikiran. Pemahaman itu bersifat dinamis dengan demikian pemahaman bersifat kreatif, suatu pemahaman akan menciptakan imajinasiimajinasi dengan pikiran yang tenang. Menurut Nana Sudjana (2006:24) dalam Supriatna (2016:43) pemahaman dapat dibedakan dalam tiga kategori, yaitu: a) tingkat terendah adalah pemahaman terjemah, mulai terjemah dalam arti sebenarnya. Pemahaman terjemah, yakni kesanggupan memahami makna yang terkandung didalamnya; b) tingkat kedua adalah pemahaman penafsiran yakni menghubungkan bagian-bagian dengan yang diketahui berikutnya atau menghubungkan beberapa bagian dari grafik dengan kejadian membedakan yang pokok dan yang bukan pokok, membedakan dua konsep yang berbeda; c) pemahaman ektrapolasi, dengan ekstrapolasi diharapkan seseorang mampu melihat dibalik yang tertulis, dapat membuat ramalan tentang konsekuensi atau dapat memperluas persepsi dalam arti waktu, dimensi, kasus ataupun masalahnya. Pemahaman ektrapolasi yakni kesanggupan melihat dibalik yang tertulis, tersirat dan tersurat meramalkan sesuatu dan memperluas wawasan.

PPID Pembantu di Dinas Pariwisata Provinsi Sumatera Barat mampu menjelaskan tentang keterbukaan informasi publik dengan bahasa sendiri, bahkan pada saat peneliti menanyakan pengetahuannya tentang keterbukaan informasi publik, PPID Pembantu mampu menafsirkan sendiri tentang keterbukaan informasi publik tersebut. PPID Pembantu memahami keterbukaan informasi sebagai kewajiban pemerintah atau konsekuensi reformasi. Dalam mengimplementasikan Undang-Undang KIP, PPID Pembantu mempersiapkan diri dalam memberikan pelayanan informasi publik, berbagai upaya yang dilakukan oleh PPID Pembantu antara lain: 1) menindaklanjuti setiap pemohon informasi; 2) membangun sistem pelayanan informasi berbasis website; 3) menyuplay data-data informasi publik kepada PPID Utama untuk di publikasikan di website.

Teori Interaksionisme Simbolik dijadikan sebagai pedoman dalam membahas pemahaman PPID Pembantu terhadap keterbukaan informasi publik yang diwujudkan dalam tindakan dalam melaksanakan pelayanan informasi sesuai dengan Undang-Undang KIP. Menurut Mead dalam Supriatna (2016:46) cara manusia mengartikan dunia dan dirinya sendiri berkaitan erat dengan masyarakatnya. Mead melihat pikiran (mind) dan dirinya (self) menjadi bagian dari perilaku manusia yaitu bagian interaksinya dengan orang lain. Mead menambahkan bahwa sebelum seseorang bertindak, ia membayangkan dirinya dalam posisi orang lain dengan harapan-harapan orang lain dan mencoba memahami apa yang diharapkan orang itu. Terdapat tiga prinsip utama menurut teori Interaksionisme Simbolik, yaitu: 1) Manusia bertindak terhadap sesuatu berdasarkan makna yang ada pada sesuatu itu bagi mereka; 2) Makna diperoleh dari hasil interaksi sosial yang dilakukan dengan orang lain; 3) Tindakan sosial merupakan hasil dari tindakan-tindakan individu. Dalam hal ini, PPID Pembantu memahami keterbukaan informasi publik dengan melakukan tindakan-tindakan, seperti menyediakan sarana dan prasarana pelayanan informasi publik, membuat sistem pelayanan informasi berbasis website, dan menyuplay data-data informasi publik kepada PPID Utama untuk di publikasikan. 


\section{Makna Pemohon Informasi oleh PPID Pembantu}

Berdasarkan hasil wawancara dengan Bapak Taufik Ramadhan, MM berkenaan dengan makna "pemohon informasi", selaku PPID Pembantu di Dinas Pariwisata Provinsi Sumatera Barat adalah sebagai berikut:

"Orang-orang yang memang harus kita layani karena mereka dijamin oleh UU KIP. Pelayanan bukan melulu dalam bentuk memberikan informasi yang mereka mau, tapi lebih kepada melayani mereka sesuai Standar Operasional Prosedur (SOP). Karena dalam pelayanan informasi memiliki SOP. Maka itulah kita harus melayani mereka sesuai dengan SOP yang sudah ditetapkan dan mereka juga harus mengikuti SOP kita. Dan apabila informasinya itu memang sudah tersedia maka kita akan langsung memberikan, tetapi apabila butuh waktu maka kita layani sesuai prosedur dan meminta jangka waktu tertentu untuk memberikan informasi yang di ajukan si pemohon".

Wawancara dengan Bapak Taufik di atas dijelaskan bahwa, pemohon informasi merupakan orang yang harus dilayani oleh PPID dalam hal pemberian informasi. Informasi yang diberikan harus sesuai dengan aturan SOP di Dinas Pariwisata Provinsi Sumatera Barat. PPID dalam menjalankan tugasnya harus memahami semua peraturan yang dikeluarkan oleh pemerintah. Dalam hal ini adalah Undang-Undang KIP. PPID mengetahui makna dari pemohon informasi yang terdapat dalam Undang-Undang KIP tersebut, sehingga tidak kesulitan dalam memberikan pelayanan kepada masyarakat.

Dilihat dari fenomenologi, PPID merupakan seorang aktor yang melakukan tindakan sosial (melakukan pemaknaan terhadap pemohon informasi) yang saling terkait dengan tindakan aktor-aktor lain disekitarnya. Ketika para informan melakukan pemahaman terhadap sesuatu, mereka memaknai sesuatu secara berbeda-beda. Proses seseorang memaknai sesuatu tidak terlepas dari latar belakang, pengetahuan yang dimilikinya serta lingkungan yang memperngaruhi cara seseorang itu memandang sesuatu. Bersifat positif artinya, PPID memaknai pemohon informasi sebagai pihak yang mengajukan permohonan informasi karena memang benar-benar membutuhkan informasi yang dibutuhkan. Sehingga PPID melayani pemohon informasi tersebut sesuai dengan peraturan perundang undangan yang berlaku. Sedangkan bersifat negatif artinya PPID memaknai pemohon informasi yang memiliki tujuan bukan untuk mendapatkan informasi. Tetapi, pemohon informasi dengan alasan undang-undang tetapi memiliki tujuan lain. Seperti diungkapkan PPID Pembantu, misalnya pemohon informasi meminta informasi data-data pribadi dan meminta bertemu dengan pejabat yang ada di Dinas Pariwisata Provinsi Sumatera Barat guna untuk kepentingan lain kemudian membuat deal-deal tertentu dengan pejabat yang bersangkutan. Dalam hal ini, tujuan keterbukaan informasi sangat tidak sesuai dengan tujuan awal untuk menciptakan clean governance dan good governance.

PPID Pembantu melalui teori interaksionisme simbolik memaknai pemohon informasi tidak terlepas dari interaksi dan kondisi yang ada di sekitarnya, makna pemohon informasi menurut pandangan PPID Pembantu yaitu pemohon informasi merupakan orangorang yang telah dijamin haknya oleh UU KIP untuk meminta informasi kepada Badan Publik. Pemahaman PPID terhadap kebijakan keterbukaan informasi publik memandang 
pemohon sebagai orang yang sedang menggunakan haknya yaitu hak sebagai warga negara untuk meminta informasi.

Menurut Mead dalam Supriatna (2016:51) cara manusia mengartikan dunia dan dirinya sendiri berkaitan erat dengan masyarakatnya, Mead melihat pikiran (mind) dan dirinya (Self) menjadi bagian dari perilaku manusia yaitu bagian dengan orang lain. Mead menambahkan bahwa sebelum seseorang bertindak ia membayangkan dirinya dalam posisi orang lain dengan harapan-harapan orang lain dan mencoba memahami apa yang diharapkan orang itu. Gambaran pembahasan diatas menyimpulkan bahwa pemaknaan PPID Pembantu terhadap pemohon informasi yaitu positif, karena PPID Pembantu memaknai pemohon informasi sebagai warga negara yang sedang menggunakan haknya.

\section{Makna Keterbukaan Informasi Publik oleh PPID Pembantu}

Hasil wawancara selanjutnya dengan Bapak Taufik Ramadhan, MM, mengenai makna keterbukaan informasi publik adalah:

"Jaminan bagi masyarakat untuk mendapat informasi dari badan publik agar pengelolaan badan publik dilakukan secara transparan dan akuntabel demi menciptakan tata kelola pemerintahan/ badan publik yang lebih baik".

Berdasarkan wawancara tersebut, makna keterbukaan informasi publik menurut PPID Pembantu adalah jaminan yang diberikan oleh pemerintah terhadap masyarakat untuk mendapatkan informasi dari Badan Publik. Selanjutnya, Bapak Taufik Ramadhan, MM juga mengatakan "informasi publik yang diakses di media online sudah cukup update dari tahuntahun sebelumnya". Tidak hanya itu, beliau juga berpendapat mengenai tingkat kebutuhan masyarakat terhadap informasi seperti berikut:

"Ya memang mengalami peningkatan dari waktu ke waktu, tetapi masih belum terlalu banyak, hanya saja mengalami peningkatan”.

Berdasarkan hasil wawancara diatas, Dinas Pariwisata Provinsi Sumatera Barat mengalami peningkatan dalam hal kebutuhan masyarakat akan informasi setiap tahunnya.

Menurut teori Mead, pemaknaan PPID Pembantu terhadap keterbukaan informasi publik dapat dilihat dari (mind) yaitu kemampuan menggunakan simbol-simbol signifikan untuk menamakan objek, mendefenisikan sesuatu atau memberi makna pada sesuatu berdasarkan pada bagaimana terhadap sesuatu itu. PPID Pembantu memaknai Keterbukaan Informasi Publik dengan cara menganalisa pengaruh yang terjadi terhadap dirinya setelah berlakunya Undang-Undang KIP. Dalam hal ini Undang-Undang KIP memberikan pengaruh yang cukup besar kepada kinerja PPID Pembantu, seperti semua pekerjaan menjadi teratur, karena ada aturan yang sudah tertulis dalam Undang-Undang No 14 Tahun 2008, bahwa setiap Badan Publik diwajibkan menunjuk PPID yang bertanggungjawab atas penyimpanan, pendokumentasian, penyediaan, dan pelayanan informasi di Badan Publik.

\section{Penutup}

PPID Pembantu Dinas Pariwisata Provinsi Sumatera Barat dapat dikatakan sukses dalam memahami Undang-Undang no. 14 tahun 2008 tentang Keterbukaan Informasi Publik. 
Selain itu, pemaknaan akan pemohon informasi publik juga berhasil diinterpretasikan dengan baik oleh PPID Pembantu, yaitu sebagai warga negara yang dijamin haknya oleh UndangUndang dalam memperoleh informasi. Selanjutnya, pemaknaan dari Keterbukaan Informasi Publik oleh PPID Pembantu adalah terorganisirnya seluruh informasi di Dinas Pariwisata Provinsi Sumatera Barat sehingga membuat pekerjaan menjadi lebih teratur. Keberhasilan pemahaman dan pemaknaan Undang-Undang KIP oleh PPID Pembantu Dinas Pariwisata Provinsi Sumatera Barat, ikut memberikan konstribusi terhadap keberhasilan Pemerintah Provinsi Sumatera Barat menjadi Provinsi yang informatif.

\section{DAFTAR KEPUSTAKAAN}

Helmi, Rahmadhona Fitri. 2007. Government Website Usage by Officials Manager of Information and Documentation in Implementation of Public Information Disclosure Law for Realization of Good Governance (Case Study: Padang City Government And Padang Pariaman Local Government). Proceeding Annual Conference on Economics, Business, Accounting and Social Sciences (ACEBASS). ISBN: 978-602-5539-03-9

Jebarus, Felik. 2014. Pemaknaan tentang Kebebasan Informasi Publik Menuju Pemerintahan Indonesia yang Bersih. Jurnal Ilmu Komunikasi. 12 (2), 180-198.

Komisi Informasi (KI) Pusat RI. 2018. Laporan Implementasi Keterbukaan Informasi Publik dan Penganugerahan Keterbukaan Informasi Badan Publik. Jakarta, Istana Wakil Presiden.

Laksmi. 2017. Teori Interaksionisme Simbolik dalam Kajian Ilmu Perpustakaan dan Informasi. PUSTABIBLIA: Journal of Library and Information Science. 1 (1), 121-138.

Lareta, AD Pahda Debby. 2014. Implementasi Undang-Undang Nomor 14 Tahun 2008 Tentang Keterbukaan Informasi Publik Dalam Penyelenggaraan Pemerintahan di Kabupaten Solok. Tesis. Prodi Magister Ilmu Komunikasi Fakultas Ilmu Sosial dan Ilmu Politik,Universitas Andalas.

Lubis, Muharman, Tien Fabrianti Kusumasari, Lukmanul Hakim. 2018. The Indonesia Public Information Disclosure Act (UU-KIP): Its Challenges and Responses. International Journal of Electrical and Computer Engineering (IJECE), 8 (1), 94-103.

Moleong, Prof. DR. Lexy, J, MA. 2017. Metode Penelitian Kualitatif, Edisi Revisi. Bandung: PT. Remaja Rosda Karya.

Morissan, M. A. 2013. Teori Komunikasi Massa. Bogor. PT Ghalia Indonesia.

Pemerintah Indonesia. 2008. Undang-Undang No. 14 Tahun 2008 tentang Keterbukaan Informasi Publik. Lembaran RI Tahun 2008 No. 61. Jakarta: Sekretariat Negara.

Primadoni. 2018. Keterbukaan Informasi Publik Wujudkan Pemerintahan yang Demokratis. https://www.covesia.com/archipelago/baca/61781/keterbukaan-infor masi-publikwujudkan-pemerintahan-yang-demokratis, diakses 24 Maret 2020.

Setiaman, Agus, Dadang Sugiana, Jimi Narotama M. 2013. Implementasi Kebijakan Keterbukaan Informasi Publik. Jurnal Kajian Komunikasi. 1 (2), 196-205. 
Siregar, Nina Siti Salmaniah. 2011. Kajian Tentang Interaksionisme Simbolik. Jurnal Ilmu Sosial-Fakultas ISIPOL UMA. 4 (2), 110

Sobur, Alex. 2017. Semiotika Komunikasi. Bandung: Remaja Rosdakarya.

Sugiyono. 2015. Metode Penelitian Kuantitatif, Kualitatif, dan R\&D. Bandung: Alfabeta.

Supriatna, Kusma. 2016. Kontra Produktif Keterbukaan Informasi Publik. Jurnal Lontar. 4 (3), 30-53. 